\title{
Lipase and esterase - to what extent can this classification be applied accurately?
}

Lipases e esterases: como definir e classificar?

\author{
Danielle Branta LOPES ${ }^{1}$, Laira Priscila FRAGA ${ }^{1}$, Luciana Francisco FLEURI², Gabriela Alves MACEDO ${ }^{1}$
}

\begin{abstract}
Enzyme technology is an ever-growing field of knowledge and, in recent years, this technology has raised renewed interest, due to the search for new paradigms in several productive processes. Lipases, esterases and cutinases are enzymes used in a wide range of processes involving synthesis and hydrolysis reactions. The objective of this work was to investigate and compare the specific lipase and esterase activities of five enzymes - four already classified as lipases and one classified as cutinase - in the presence of natural and synthetic substrates. All tested enzymes presented both esterase and lipase specific activities. The highest specific esterase activity was observed for Aspergillus 1068 lipase in natural substrate and for F. oxysporum cutinase in synthetic substrate, while the highest specific lipase activity was observed for Geotrichum sp. lipase in natural substrate and for F. oxysporum cutinase in synthetic substrate. These results display some interface-independent lipolytic activity for all lipases tested. This is in accordance with the rationale that a new and broader definition of lipases may be necessary.

Keywords: lipase; esterase; cutinase; lipase specific activity; esterase specific activity.
\end{abstract}

\section{Resumo}

Tecnologia enzimática é um campo de conhecimento cada vez maior, e, nos últimos anos, esta tecnologia tem apresentado um interesse crescente, devido à busca de novos paradigmas em diversos processos produtivos. Lipases, esterases e cutinases são as enzimas usadas em uma ampla gama de processos que envolvem reações de síntese e hidrólise. O objetivo deste trabalho foi investigar e comparar as atividades de lipase e esterase de quatro enzimas já classificadas como lipases e uma como cutinase, na presença de substratos naturais e sintéticos. Todas as enzimas testadas apresentaram atividades específicas tanto de esterase como de lipase. A maior atividade específica de esterase foi observada para a lipase de Aspergillus 1068 em substrato natural e a cutinase de F. oxysporum em substrato sintético, enquanto a atividade específica de lipase mais alta foi observada para a lipase de Geotrichum sp. em substrato natural e a cutinase de F. oxysporum em substrato sintético. Estes resultados permitem visualizar algumas interfaces independentes de atividade lipolítica para todas as lipases testadas. De acordo com estes estudos, uma nova e mais ampla definição de lipase pode ser necessária.

Palavras-chave: lipase; esterase; cutinase; atividade específica de lipase; atividade específica de esterase.

\section{Introduction}

Esterases (EC 3.1.1.X) comprise a diverse group of hydrolases that catalyze the cleavage and formation of ester bonds. They are widely distributed in animals, plants and microorganisms. Many of them show a wide range of possible substrates, leading to the assumption that they evolved to enable access to carbon sources or to be involved in catabolic pathways. These enzymes also display high regio- and stereo-specificity, making them attractive biocatalysts in the production of optically pure compounds in fine chemical synthesis.

Two major classes of hydrolases are of utmost importance: 'true' esterases (EC 3.1.1.1, carboxyl ester hydrolases) and lipases (EC 3.1.1.3, triacylglycerol hydrolases) (BORNSCHEUER, 2002). Lipases are mainly active against water-insoluble substrates, such as triglycerides composed by long-chain fatty acids, whereas esterases preferentially hydrolyze 'simple' esters and usually only triglycerides composed by fatty acids shorter than $\mathrm{C}_{6}$ (HELISTÖ; KORPELA, 1998; KULKARNI; GADRE, 2002).
Lipases can be distinguished from carboxyl esterases by their substrate spectra, using $p$-nitrophenyl palmitate (cleaved by lipases) versus $p$-nitrophenyl butyrate (cleaved by esterases). Lipases can also be distinguished from esterases by the phenomenon of interfacial activation, which is only observed for lipases. Both enzymes remain stable in organic solvents, but this property is more noticed for lipases (Bornscheuer, 2002).

According to Brenda (2007), cutinases can be classified as EC 3.1.1.3, the recommended name being triacylglycerol lipase, and the systematic name triacylglycerol acyl hydrolyse. The same source also classifies it as 3.1.1.74, the recommended name being cutinase and the systematic name cutin hydrolyse. It is first considered as an esterase that hydrolyzes cutin, but can also works as and be classified as lipase.

Cutinases are characterized by the ability to degrade cutin, the biopolyester that forms the cuticle of higher plants. They were first described in phytopathogenic fungi that grow on cutin as the sole carbon source, cleaving the ester bonds

${ }^{1}$ Departamento de Ciência de Alimentos, Faculdade de Engenharia de Alimentos - FEA/DCA, Universidade Estadual de Campinas - UNICAMP, Campinas, SP, Brasil

2 Departamento de Química e Bioquímica, Instituto de Biociências de Botucatu - IBB/DQB, Universidade Estadual Paulista "Júlio de Mesquita Filho" - UNESP, Distrito de Rubião Jr., s/n, CEP 18618-970, Botucatu, SP, Brasil,e-mail: luciana@ibb.unesp.br

${ }^{*}$ Corresponding author 
in the cutin polymer (KOLATTUKUDY, 1984; ETTINGER; THUKRAL; KOLATTUKUDY, 1987; EGMOND; VLIEG, 2000). Cutinases are also able to hydrolyze a great variety of synthetic esters, being as efficient as pancreatic lipases on short and long chains of emulsified triacylglycerols (DE GEUS; LAWEREYS; MATTHYSSENS, 1989). Cutinases are active regardless of the presence of a lipid-water interface, either in soluble and emulsified triglycerides (VERGER; HAAS, 1976; LONGHI; CAMBILLAU, 1999; MACEDO; PIO, 2005; PIO; MACEDO, 2007).

Comparisons between carboxylesterases and lipases reveal remarkable sequence similarities in spite of radically different substrate specificities or physiological functions (SCHRAG; CYGLER, 1993; LIN; WU; CHEN, 2001; BENCHARIT et al., 2002; 2003a,b).

The comparative analysis of three-dimensional structures of esterases and lipases reveals a feature known as $\alpha / \beta$ hydrolase fold, which consists of a central $\beta$-sheet surrounded by a variable number of $\alpha$-helices, and accommodates a catalytic triad composed of serine, histidine, and a carboxylic acid (OLLIS et al., 1992; CYGLER et al., 1993; HOLMQUIST, 2000). The database ESTHER- Esterases, $\alpha / \beta$ Hydrolase Enzymes and Relatives (INLAND NORTHWEST RESEARCH ALLIANCE, 2007) lists the three-dimensional structures of all known $\alpha / \beta$ hydrolase fold proteins.

Many lipases and esterases have their active site buried under secondary structural elements that must change conformation to allow substrate access to the active site. These secondary structure elements have been called caps, lids or flaps, and have important roles in regulating accessibility of substrates into the catalytic device.

Hydrolytic enzymes such as lipases and esterases can also catalyze synthesis reactions, once the chemical equilibrium is shifted into the direction of the synthesis reaction (STAMATIS et al., 1998).

Teng and Xu (2007) compared two methods: colorimetric and CG-FID, to test the lipase activity for many commercial lipases. They concluded that using $p$-NPP the measurement time was greatly shortened and contributed to evaluate the lipase activity in organic solvent.

Titrimetric methods tend to be time consuming, which may render them unsuitable for large-scale screening of lipolytic activity (THOMSON; DELAQUIS; MAZZA, 1999).

Many literature citations report the use of synthetic substrates for the measurement of lipase activity. In particular, $p$-nitrophenyl derivatives of fatty acids (generally lauric or palmitic acids) have been popular (BECKER et al., 1997; LABUSCHAGNE; VAN TONDER; LITTHAUER, 1997).

Vorderwulbecke, Kieslich and Erdmann (1992), in a study of Geotrichum candidum lipase, tested the lipolytic activity using $p$-NPP and the esterase activity using $p$-NPB. Titrimetric methods for lipase activity determination are widly employed and seem to offer adequate sensitivity in many applications. The method requires little or non-sophisticated equipment and the analysis is straightforward. However, some authors suggest that successful measurement of lipase activity by titration requires stable emulsions and absolute control of $\mathrm{pH}$ during hydrolysis (DE
MONPEZAT et al., 1990). Method performance may be enhanced by ensuring electrodes are thoroughly cleaned between assays.

Ghamgui, Karra-Chaâbouni and Gargouri (2004) used the titrimetric method to measure the activities of free and immobilized lipases from Rhizopus oryzae, using olive oil emulsion as substrate. The same method was used by Macedo, Park and Pastore (1997) to measure the activity for Geotrichum candidum lipase, achieving $6.22 \mathrm{U} \cdot \mathrm{mL}^{-1}$.

The objective of the present work was to investigate the esterase and lipase specific activities of four lipases and one cutinase, which were isolated in the biochemistry laboratory of the Faculty of Food Engineering at Campinas State University, and one commercial lipase (Lipozyme), in the presence of natural and synthetic substrates.

\section{Materials and methods}

\subsection{Enzymes}

Geotrichum sp. lipase was obtained according to Macedo (1995). Lipases from Aspergillus sp. strains 1068 and 1099 were produced according to Costa (1996). Rhizopus sp. lipase was produced by Costa (1997). Lipozyme TL IM lipase was obtained from Novozymes ${ }^{\oplus} \mathrm{A} / \mathrm{S}$.

Cutinase from Fusarium oxysporum was obtained according to Pio and Macedo (2007).

\subsection{Esterase assays}

\section{Method 1: Assay using olive oil as substrate}

Esterase activity was performed with olive oil, which was prepared as follows: the reaction mixture containing $5 \mathrm{~mL}$ of olive oil, $2 \mathrm{~mL}$ of $0.1 \mathrm{M}$ phosphate buffer ( $\mathrm{pH} 7.0)$ and $1 \mathrm{~mL}$ of the enzymatic extract $\left(10 \mathrm{mg} \cdot \mathrm{mL}^{-1}\right)$ was incubated at $37^{\circ} \mathrm{C}$ for 30 minutes with orbital shaking. Immediately after incubation, the system was disrupted by the addition of $15 \mathrm{~mL}$ of acetone-ethanol mixture $(1: 1 \mathrm{v} / \mathrm{v})$ and the liberated free fatty acids were titrated with $0.05 \mathrm{M} \mathrm{NaOH}$. All assays were done independently and in duplicate. One unit of esterase activity was defined as the amount of enzyme which liberated $1 \mu \mathrm{mol}$ of fatty acids per minute.

\section{Method 2: Assay using p-nitrophenyl butyrate (pNPB) as substrate}

Esterase activity was determined spectrophotometrically following the hydrolysis of $p$-nitrophenylbutyrate ( $p \mathrm{NPB}$ ) at $405 \mathrm{~nm}$. An aliquot $(0.070 \mathrm{~mL})$ of the enzyme suspension (10 mg.mL $\mathrm{mL}^{-1}$ ) was added to $3.43 \mathrm{~mL}$ of a reaction mixture with the following composition: $1.12 \mathrm{mM} p \mathrm{NPB}$ dissolved in $50 \mathrm{mM}$ phosphate buffer, $\mathrm{pH}$ at 7.2, also containing $0.2 \%(\mathrm{~N} / \mathrm{P})$ Triton $\mathrm{X}-100$ and $0.43 \mathrm{M}$ tetrahydrofuran. The reaction was monitored for 15 minutes against blank solution (CALADO et al., 2002). All assays were carried out independently and in duplicate. One unit of esterase activity was defined as the amount of esterase required to release $1 \mu \mathrm{mol}$ of $p$-nitrophenol in one minute, under the specified conditions. $p$ NPB was purchased from Sigma-Aldrich Brasil (Sao Paulo, Brazil). 


\subsection{Effect of surfactant concentration on enzyme activity}

The esterase activity was determined using $p \mathrm{NPB}$ as substrate according to item 2.2 The concentration of the Triton $\mathrm{X}-100$ varied between zero and $0.8 \%(\mathrm{w} / \mathrm{w})$. The tests were performed twice and the mean values were compared using the Tukey's test, at a confidence interval of $95 \%$ and significant level of $p \leq 0.05$. The data analysis was carried out using the software "Statistic for Windows" (Microsoft, 1995).

\subsection{Lipase assays}

\section{Method 1: Assay using olive oil as substrate}

Lipase activity was determined using an olive oil emulsion, which was prepared as follows: $25 \mathrm{~mL}$ of olive oil and $75 \mathrm{~mL}$ of $7 \%$ arabic gum solution were emulsified in liquefier for 2 minutes. The reaction mixture containing $5 \mathrm{~mL}$ of olive oil emulsion, $2 \mathrm{~mL}$ of $0.1 \mathrm{M}$ phosphate buffer $(\mathrm{pH} 7.0)$ and $1 \mathrm{~mL}$ of the enzymatic suspension $\left(10 \mathrm{mg} \cdot \mathrm{mL}^{-1}\right)$ was incubated at $37^{\circ} \mathrm{C}$ for 30 minutes with orbital shaking. Immediately after incubation, the emulsion was disrupted by the addition of $15 \mathrm{~mL}$ of acetone-ethanol $(1: 1 \mathrm{v} / \mathrm{v})$ and the liberated free fatty acids were titrated with $0.05 \mathrm{M} \mathrm{NaOH}$ (MACEDO; PARK; PASTORE, 1997). All assays were carried out independently and in duplicate. One unit of lipase activity was defined as the amount of enzyme which liberated $1 \mu \mathrm{mol}$ of fatty acids per minute.

\section{Method 2: Assay using p-nitrophenyl palmitate as substrate}

A spectrophotometric method was used for fast and routine measurement of lipase activity using $p$-nitrophenylpalmitate ( $p$ NPP) as the substrate (MAHADIK et al., 2002). The assay mixture consisted of $0.9 \mathrm{~mL}$ of substrate solution, $0.1 \mathrm{~mL}$ of suitable buffer $(0.5 \mathrm{M})$ and $0.1 \mathrm{~mL}$ of suitable diluted enzyme. The assay mixture was incubated at $37{ }^{\circ} \mathrm{C}$ for 30 minutes and the $p$-nitrophenol released was measured at $410 \mathrm{~nm}$ in
Spectronic-117 spectrophotometer. All assays were performed independently and in duplicate. One lipase unit (U) was defined as the amount of enzyme needed to release $1 \mu \mathrm{mol}$ of $p$-nitrophenol per minute. pNPP was purchased from Sigma-Aldrich Brasil (São Paulo, Brazil).

\subsection{Total protein assays}

Total protein concentration was determined according to the Bradford (1976) method.

\section{Results and discussion}

\subsection{Esterase assays}

All enzymes tested, in triplicate, displayed detectable specific esterase activity on both natural and synthetic substrates. The esterase activity was higher in the presence of the natural substrates compared to the synthetic ones for all enzymes tested. Data concerning the specific esterase activity for cutinase and all non-commercial lipases are shown in Figure 1.

Cutinase displayed the highest activity in the presence of the synthetic substrate and the smallest activity in the presence of the natural substrate, among all non-commercial enzymes tested.

In the lipase group, the higher specific esterase activity was registered for the commercial preparation Lipozyme ${ }^{\mathrm{mm}}$ (specific esterase activity employing the natural substrate was 187.3 U.mg ${ }^{-1}$ and for the synthetic substrate was $1.8 \mathrm{U} \cdot \mathrm{mg}^{-1}$ ), followed by Aspergillus 1068 lipase, regardless of the employed method.

\subsection{Effect of surfactant concentration on enzyme activity}

Enzymatic activities measured, in triplicate, with and without the presence of the surfactant Triton X-100 are displayed in Table 1. With respect to Aspergillus 1068 and Aspergillus 1099

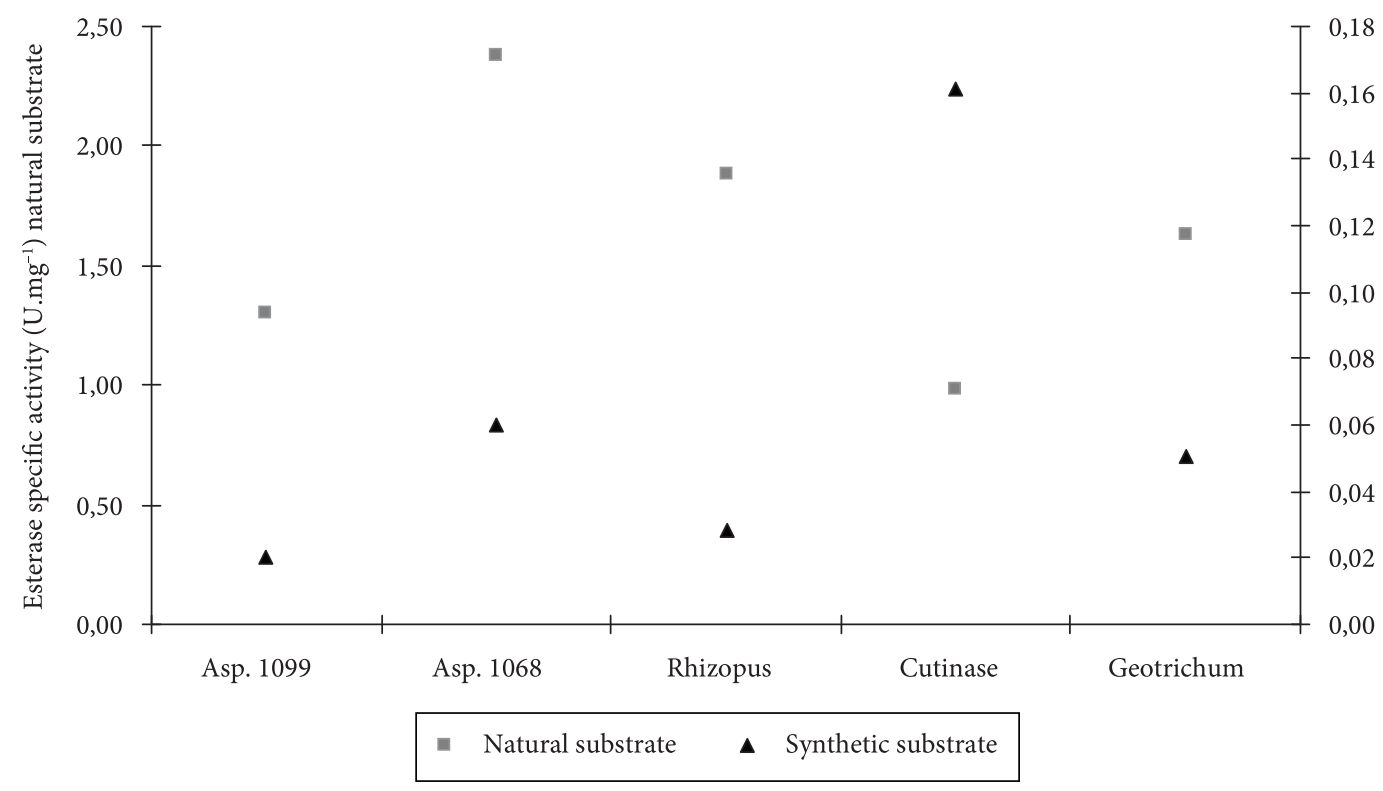

Figure 1. Specific esterase activity $\left(\mathrm{U} \cdot \mathrm{mg}^{-1}\right)$. 
lipases, the addition of Triton X-100 resulted in a decrease in the enzymatic activity regardless of the Triton concentration. The Rhizopus lipase presented the highest activity in the presence of $0.4 \%$ Triton X-100, but also presented activity, although smaller, without the surfactant.

The lipase from Geotrichum sp. showed discrete influence by the presence of Triton X-100, being observed only a tendency of decrease in the enzymatic activity with the increase in Triton concentration.

The Lipozyme ${ }^{\mathrm{Tw}}$ displayed a behavior similar to Rhizopus lipase, although with higher activities overall.

The cutinase activity was statistically the same in the absence or in the presence of Triton X-100 0.2\%. However, the enzymatic activity was smaller in the presence of 0.4 and $0.8 \%$ surfactant concentrations.

Nozaki, Reynolds and Tanford (1974) described three interaction levels between proteins and surfactants. The first level predicts possible associations involving bonding sites on the protein molecular surface. The second level describes a cooperative association between the protein and a large number of surfactant molecules, without major conformational changes.

Table 1. Enzyme activity $\left(\mathrm{U} \cdot \mathrm{mg}^{-1}\right)$ using $\mathrm{pNPB}$ as substrate in the presence of different Triton X-100 concentrations, submitted to analysis through Tukey's test, at a 95\% confidence interval.

\begin{tabular}{lrrrr}
\hline \multirow{2}{*}{ Enzyme } & \multicolumn{4}{c}{ Triton X-100 concentration \% (v/v) } \\
\cline { 2 - 5 } & \multicolumn{1}{c}{0} & 0.2 & 0.4 & $0.8^{2}$ \\
\hline Lipase (Aspergillus 1068) & $6.3_{\mathrm{C}}$ & $1.4_{\mathrm{A}}$ & $1.0_{\mathrm{A}}$ & $1.0_{\mathrm{A}}$ \\
Lipase (Aspergillus 1099) & $2.2_{\mathrm{A}}$ & $0.2_{\mathrm{A}}$ & $0.5_{\mathrm{A}}$ & $0.3_{\mathrm{A}}$ \\
Lipase (Rhizopus sp.) & $3.1_{\mathrm{B}}$ & $1.4_{\mathrm{A}}$ & $6.0_{\mathrm{C}}$ & $1.3_{\mathrm{A}}$ \\
Lipase (Geotrichum sp.) & $4.9_{\mathrm{B}}$ & $3.6_{\mathrm{B}}$ & $3.2_{\mathrm{B}}$ & $2.8_{\mathrm{AB}}$ \\
Lipase (Lipozyme TL IM $\left.{ }^{\otimes}\right)$ & $1.8_{\mathrm{C}}$ & $7.8_{\mathrm{C}}$ & $15.6_{\mathrm{E}}$ & $4.5_{\mathrm{B}}$ \\
Cutinase (F. oxysporum) & $10.9_{\mathrm{D}}$ & $10.4_{\mathrm{D}}$ & $7.0_{\mathrm{C}}$ & $7.8_{\mathrm{C}}$ \\
\hline
\end{tabular}

The third level comprises a cooperative association with protein denaturation.

Unlike anionic and cationic tensoactives, which are generally denaturant to proteins, non-ionic tensoactives like Triton X-100 do not induce conformational changes with loss of biologic properties in proteins.

Triton X-100 has a restrict capacity to break protein-protein bonds, and most proteins retain their quaternary structure even in the presence of high concentrations of this tensoactive. Triton X-100 is well fitted for determination of lipase hydrolytic activity (ROCHA, 1999).

Kim et al. (2002), in a study of characterization of an esterase from Pseudomonas sp. S34 with high stereospecificity to ketoprofen ethyl ester, observed that the enzyme activity was markedly increased (four-fold) with addition of the non-ionic detergent Triton X-100.

Choi et al. (2003) studied the activity of an esterase from E. coli KCTC1767 in the presence of several surfactants, observing that the highest activity occurred in the presence of Triton X-100.

Prazeres, Cruz and Pastore (2006) tested the influence of different surfactants in the activity of Fusarium oxysporum lipase. It was concluded that the addition of $10 \%$ Triton-X had a positive influence on the enzyme activity.

\subsection{Lipase assays}

All the enzymes tested in triplicate displayed detectable specific lipase activity in the presence of natural and synthetic substrates. On the whole, the highest activities were registered for Lipozyme ${ }^{\mathrm{mt}}$ (the specific lipase activity employing the natural

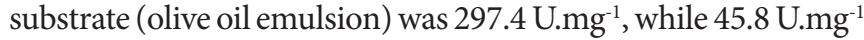
was registered for the synthetic substrate $(p N P P)$. Figure 2 presents the values of specific lipase activities in the presence of synthetic and natural substrates only for non-commercial enzymes. Among these, the highest activities were observed for

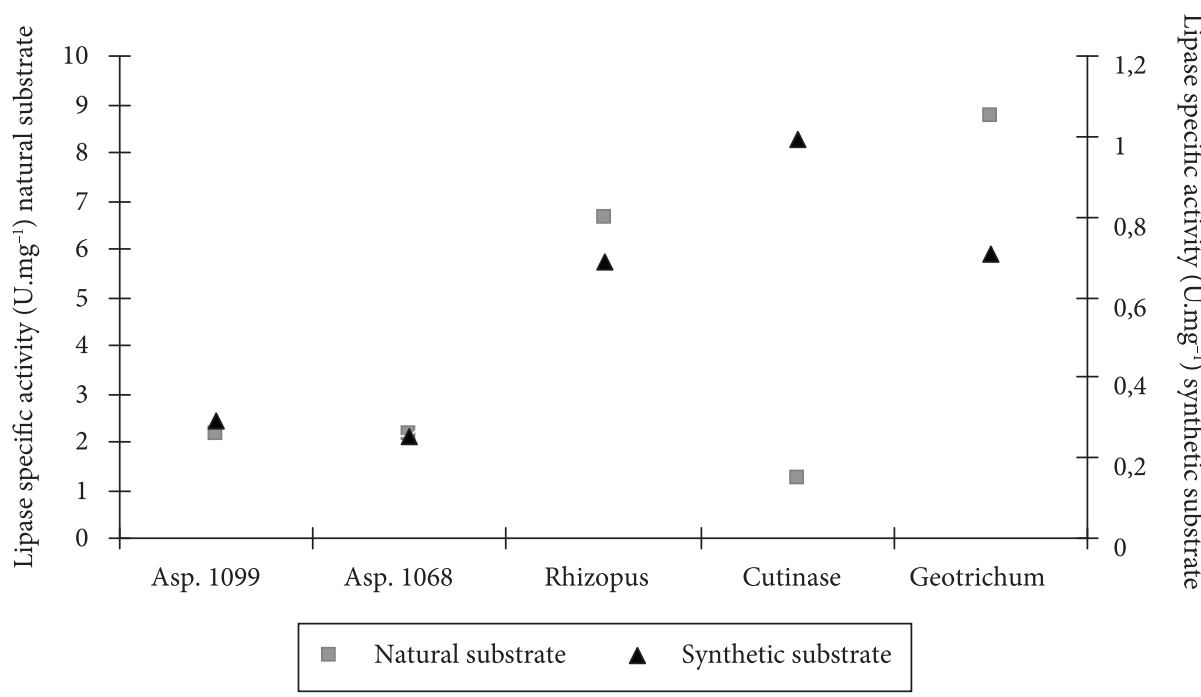

Figure 2. Specific lipase activity $\left(\mathrm{U} \cdot \mathrm{mg}^{-1}\right)$. 
Geotrichum sp. lipase in the presence of natural substrate, and for F. oxysporum cutinase in the presence of synthetic substrate.

Cutinase also registered the smallest activity in the presence of the natural substrate. The specific lipase activity profiles of Aspergillus 1099 and Aspergillus 1068 lipases were very similar, both in the presence of natural and synthetic substrates.

According to their current definition, lipases are enzymes that hydrolyze emulsified triglycerides. Due to the broad field of biotechnological applications of these enzymes, this definition is becoming insufficient, and a new and more comprehensive one is necessary.

Lipases are classified by Vorderwulbecke, Kieslich and Erdmann (1992) as enzymes that hydrolyze and also synthesize esters; they can also act regardless of the presence of an interface, under well-established conditions, retaining catalytic activity in either organic or non-organic solvents. This new definition poses a challenge to define lipolytic activity, and to select the standard assay. However, there is no universal assay, and the use of the same method, in the same organism, can result in different values, due to differences in storage time, purification process and source of the microorganism.

The use of water-soluble substrates, such as $p$-nitrophenyl palmitate ( $p$ NPP) (MAHADIK et al., 2002), presents some advantages, due to their short reaction time and easy readings through spectrophotometry. However, these substrates are not the most adequate to determine of true lipase activity, because they are also hydrolyzed by esterases (ERDMANN et al., 1990). Pending this limitation, the use of this substrate in a spectrophotometry assay for determination of lipase activity in organic media is well described by Pencreac'h and Baratti (1996).

The most employed method for lipase activity determination performs the titrating of free fatty acids generated from triglyceride hydrolysis, in an emulsion stabilized by a tensoactive agent. Arabic gum is described as an adequate tensoactive agent, resulting in high values of lipolytic activity, although the effect of emulsifiers in the activity of microbial lipases is not thoroughly understood (VEERARAGAVAN, 1990).

\section{Conclusions}

All enzymes tested displayed both esterase and lipase specific activities. The highest specific esterase activity was observed for Aspergillus 1068 lipase in natural substrate and F. oxysporum cutinase in $p$ NPB substrate. For lipase, the highest activity was observed for Geotrichum sp. lipase in natural substrate and F. oxysporum cutinase in $p$ NPP. F. oxysporum cutinase displayed the highest specific lipase and esterase activities in the presence of synthetic substrate, among all enzymes tested.

Considering the biotechnological applications of lipases, the current definition of these enzymes as being able to hydrolyze emulsified triglycerides is really insufficient, becoming necessary the development of a new and broader definition, which is already being suggested in the literature. The results of this study are in accordance with the rationale that lipases should be classified as enzymes which are able to catalyze reactions of hydrolysis and synthesis of esters and are also able to react, regardless of the presence of an interface under well-defined experimental parameters. The definition of lipolytic activity is a difficult task in the context of this new lipase definition. The enzyme should not be defined through a single method of activity determination and the complete biochemical characterization of the enzyme is essential.

\section{Acknowledgements}

The authors are grateful to 'Conselho Nacional de Desenvolvimento Científico e Tecnológico' (CNPq) and to 'Fundação de Amparo à Pesquisa do Estado de São Paulo' (FAPESP) their financial support.

\section{References}

BECKER, P. et al. Determination of the kinetic parameters during continuous cultivation of the lipase producing thermophile Bacillus sp. on olive oil. Applied Microbiology and Biotechnology, v. 48, n. 2, p. 184-190, 1997. PMid:9299775. http://dx.doi. org/10.1007/s002530051036

BENCHARIT, S. et al. Structural insights into CPT-11 activation by mammalian carboxylesterases. Nature Structural Biology, v. 9, n. 5, p. 337-342, 2002. PMid:11967565. http://dx.doi.org/10.1038/nsb790

BENCHARIT, S. et al. Crystal structure of human carboxylesterase 1 complexed with the Alzheimer's drug tacrine: from binding promiscuity to selective inhibition. Chemistry \& Biology, v. 10, n. 4, p. 341-349, 2003a. http://dx.doi.org/10.1016/S1074-5521(03)00071-1

BENCHARIT, S. et al. Structural basis of heroin and cocaine metabolism by a promiscuous human drug-processing enzyme. Nature Structural Biology, v. 10, n. 5, p. 345-356, 2003 b. PMid:12679808. http://dx.doi.org/10.1038/nsb919

BORNSCHEUER, U. T. Microbial carboxyl esterases: classification, properties and application in biocatalysis. FEMS Microbiology Reviews, v. 26, n. 1, p. 73-81, 2002. PMid:12007643. http://dx.doi. org/10.1111/j.1574-6976.2002.tb00599.x

BRADFORD, M. M. A rapid and sensitive method for the quantitation of microgram quantities of protein utilizing the principle of protein-dye binding. Analytical Biochemistry, v. 72, p. 248-254, 1976. http://dx.doi.org/10.1016/0003-2697(76)90527-3

BRENDA. Disponível em: <http://www.brenda-enzymes.info $>$. Acesso em: 30 ago. 2007.

CALADO, C. R. C. et al. Effect of pre-fermentation on the production of cutinase by a recombinant Saccharomyces cerevisiae. Journal of Bioscience and Bioengineering, v. 93, n. 4, p. 354-359, 2002.

CHOI, G. S. et al. Construction and characterization of a recombinant esterase with high activity and enantioselectivity to (S)-ketoprofen ethyl ester. Protein Expression and Purification, v. 29, n. 1, p. 85-93, 2003. http://dx.doi.org/10.1016/S1046-5928(03)00009-3

COSTA, M. C. Produção, purificação e caracterização da lipase de Aspergillus sp. 1996. 107 f. Dissertação (Mestrado em Tecnologia dos Alimentos)-Universidade Estadual de Campinas, Campinas, 1996.

COSTA, V. R. S. Produção, purificação e caracterização bioquímica de uma nova linhagem de Rhizopus sp. 1997. 78 f. Dissertação (Mestrado em Tecnologia dos Alimentos)-Universidade Estadual de Campinas, Campinas, 1997.

CYGLER, M. et al. Relationship between sequence conservation and three-dimensional structure in a large family of esterases, lipases, and related proteins. Protein Science, v. 2, p. 366-382, 1993. PMid:8453375. http://dx.doi.org/10.1002/pro.5560020309 
DE GEUS, P.; LAWEREYS, M.; MATTHYSSENS, G. European Patent application No PCT 89.400462.1, 1989.

DE MONPEZAT T, L. et al. A fluorimetric method for measuring lipase activity based on umbelliferyl esters. Lipids, v. 25, n. 10, p. 661-664, 1990. http://dx.doi.org/10.1007/BF02536018

EGMOND, M. R.; DE VLIEG, J. Fusarium solani pisi cutinase. Biochimie, v. 82, n. 11, p. 1015-1022, 2000. http://dx.doi. org/10.1016/S0300-9084(00)01183-4

ERDMANN, H. et al. Comparison of lipase activities by different assays. In: ALBERGHINA, L.; SCHMID, R.D.; VERGER, R. (Eds.). Lipases: Structure, Mechanism and Genetic Engineering. Braunschweig: GBF Monographs, 1990. p. 425-428.

ETTINGER, W. F.; THUKRAL, S. K.; KOLATTUKUDY, P. E. Structure of cutinase gene, cDNA, and the derived amino acid sequence from phytopathogenic fungi. Biochemistry, v. 26, p. 7883-7892, 1987. http://dx.doi.org/10.1021/bi00398a052

GHAMGUI, H.; KARRA-CHAÂBOUNI, M.; GARGOURI, Y. 1-Butyl oleate synthesis by immobilized lipase from n-hexane and solvent-free system. Enzyme and Microbial Technology, v. 35, n. 4, p. 355-363, 2004. http://dx.doi.org/10.1016/j.enzmictec.2004.06.002

HELISTÖ, P.; KORPELA, T. Effects of detergents on activity of microbial lipases as measured by the paranitrophenyl alkanoate esters method. Enzyme and Microbial Technology, v. 23, n. 1-2, p. 113-117, 1998. http://dx.doi.org/10.1016/S0141-0229(98)00024-6

HOLMQUIST, M. Alpha Beta-Hydrolase Fold Enzymes Structures, Functions and Mechanisms. Current Protein and Peptide Science, v. 1, n. 2, p. 209-235, 2000. PMid:12369917. http://dx.doi. org/10.2174/1389203003381405

INLAND NORTHWEST RESEARCH ALLIANCE - INRA. Esters database. Montpellier: INRA. Disponível em: <www.ensam.inra. fr/cholinesterase>. Acesso em: 20 ago. 2007.

KIM, G. S. et al. Screening, production and properties of a stereospecific esterase from Pseudomonas sp. S34 with high selectivity to (S)-ketoprofen ethyl ester. Journal of Molecular Catalysis B: Enzymatic, v. 17, n. 1, p. 29-38, 2002. http://dx.doi.org/10.1016/ S1381-1177(01)00077-7

KOLATTUKUDY, P. E. Cutinases from fungi and pollen. In: BORGSTROM, B.; BROCKMAN, H. (Eds.). Lipases. Amsterdam: Elsevier, 1984. p. 471-504.

KULKARNI N.; GADRE, R. V. Production and properties of alkaline, thermophilic lipase from Pseudomonas fluorenscens NS2W. Journal of Industrial Microbiology and Biotechnology, v. 28, n. 6, p. 344-348, 2002. PMid:12032808. http://dx.doi.org/10.1038/ sj.jim.7000254

LABUSCHAGNE, R. B.; VAN TONDER, A.; LITTHAUER, D. Flavobacterium odoratum lipase: isolation and characterization. Enzyme Microbial Technology, v. 21, n. 1, p. 52-58, 1997. http://dx.doi.org/10.1016/S0141-0229(96)00226-8

LIN, Y.C.; WU,J. Y.; CHEN, T.L. Production of Acinetobacter radioresistens lipase with repeated batch culture in presence of nonwoven fabric. Biotechnology and Bioengineering, v. 76, n. 3, p. 214-218, 2001. PMid:11668456. http://dx.doi.org/10.1002/bit.1185

LONGHI, S.; CAMBILLAU, C. Structure-activity of cutinase, a small lipolytic enzyme. Biochimica et Biophysica Acta (BBA) Molecular and Cell Biology of Lipids, v. 1441, n. 2-3, p. 185-196, 1999.

MACEDO, G. A. Produção, purificação, caracterização bioquímica e aplicações de lipase de Geotrichum sp. 1995. 121 f. Dissertação (Mestrado em Tecnologia dos Alimentos)-Universidade Estadual de Campinas, Campinas, 1995.

MACEDO, G. A.; PARK, Y. K.; PASTORE, G. M. Partial purification and characterization of an extracellular lipase from a newly isolated strain of Geotrichum sp. Brazilian Journal of Microbiology, v. 39, p. 687-692, 1997.

MACEDO, G. A.; PIO, T. F. A rapid screening method for cutinase producing microorganisms. Brazilian Journal of Microbiology, v. 36, n. 4, p. 388-394, 2005. http://dx.doi.org/10.1590/S151783822005000400016

MAHADIK, N. D. et al. Production of acidic lipase by Aspergillus niger in solid state fermentation. Process Biochemistry, v. 38, n. 5, p. 715- 721, 2002. http://dx.doi.org/10.1016/S0032-9592(02)00194-2

NOZAKI, Y.; REYNOLDS, J. A.; TANFORD, C. The interaction of a cationic detergent with bovine serum albumin and other proteins. The Journal of Biological Chemistry, v. 249, n. 14, p. 4452-4459, 1974.

OLLIS, D. L. et al. The $\alpha / \beta$ hydrolase fold. Protein Engineering, v. 5, n. 3, p. 197-211, 1992. http://dx.doi.org/10.1093/protein/5.3.197

PENCREAC'H, G.; BARATTI, J. C. Hydrolysis of $p$-nitrophenyl palmitate in $n$-heptane by the Pseudomonas cepacia lipase: A simple test for the determination of lipase activity in organic media. Enzyme and Microbial Technology, v. 18, n. 6, p. 417-422, 1996. http://dx.doi.org/10.1016/0141-0229(95)00120-4

PIO, T. F.; MACEDO, G. A. Optimizing the production of cutinase by Fusarium oxysporum using response surface methodology. Enzyme and Microbial Technology, v. 42, n. 5, p. 613-619, 2007. http://dx.doi.org/10.1016/j.enzmictec.2007.05.008

PRAZERES, J. N.; CRUZ, J. A. B.; PASTORE, G. M. Characterization of alkaline lipase from Fusarium oxysporum and effect of different surfactants and detergents on the enzyme activity. Brazilian Journal of Microbiology, v. 37, n. 4, p. 505-509, 2006. http://dx.doi. org/10.1590/S1517-83822006000400019

ROCHA, J. M. S. Aplicações de agentes tensoativos em biotecnologia. Boletim de Biotecnologia, v. 64, p. 5-11, 1999.

SCHRAG, J. D.; CYGLER, M. 1.8 A Refined Structure of the Lipase from Geotrichum candidum. Journal of Molecular Biology, v. 230, n. 2, p. 575-591, 1993. PMid:8464065. http://dx.doi.org/10.1006/ jmbi.1993.1171

STAMATIS, H. et al. Studies on the synthesis of short-chain geranyl esters catalyzed by Fusarium oxysporum esterase in organic solvents. Journal of Molecular Catalysis B: Enzymatic, v. 4, n. 4, p. 229-236, 1998. PMid:17316537. http://dx.doi.org/10.1016/S13811177(98)00003-4

TENG, Y.; XU, Y. A modified para-nitrophenyl palmitate assay for lipase synthetic activity determination in organic solvent. Analytical Biochemistry, v. 363, n. 2, p. 297-299, 2007. PMid:10198753. http:// dx.doi.org/10.1016/j.ab.2007.01.026

THOMSON, C. A.; DELAQUIS, P. J.; MAZZA, G. Detection and Measurement of Microbial Lipase Activity: A Review. Critical Reviews in Food Science Nutrition, v. 39, n. 2, p. 165-187, 1999. PMid:10198753. http://dx.doi.org/10.1080/10408399908500492

VEERARAGAVAN, K. A simple and sensitive method for the estimation of microbial lipase activity. Analytical Biochemistry, v. 186, n. 2 , p. $301-305,1990$. http://dx.doi.org/10.1016/00032697(90)90084-M

VERGER, R.; DE HAAS, G. H. Interfacial enzyme kinetics of lipolysis. Annual Review of Biophysics and Bioengineering, v. 5, p. 77-117, 1976. PMid:782347. http://dx.doi.org/10.1146/annurev. bb.05.060176.000453

VORDERWULBECKE, T.; KIESLICH, K.; ERDMANN, H. Comparison of lipases by different assays. Enzyme Microbial Technology, v. 14, n. 8 , p. 631-639, 1992. http://dx.doi.org/10.1016/01410229(92)90038-P 